\title{
Effect of Ni Contents on Microstructures and Mechanical Properties for $\left(\mathrm{Ti}_{0.8} \mathbf{M o}_{0.2}\right) \mathrm{C}-\mathrm{Ni}$ Cermets
}

\author{
Hiroyuki Hosokawa, Kiyotaka Katou, Koji Shimojima, Ryoichi Furushima and Akihiro Matsumoto \\ Materials Research Institute for Sustainable Development, National Institute of Advanced Industrial Science and Technology, \\ Nagoya 463-8560, Japan
}

The $\left(\mathrm{Ti}_{0.8} \mathrm{Mo}_{0.2}\right) \mathrm{C}-x \mathrm{Ni}$ cermets $(x=10,20,30$ and 40 mass $\%)$ were prepared by two milling processes; first, the $\left(\mathrm{Ti}_{0.8} \mathrm{Mo}_{0.2}\right) \mathrm{C}$ produced by mechanical alloying of Ti, Mo and C powders (Process I). Second, mechanical alloyed $\left(\mathrm{Ti}_{0.8} \mathrm{Mo}_{0.2}\right) \mathrm{C}$ and commercial Ni powders mixed by tumbling ball milling (Process II) for $72 \mathrm{~h}$. On $\left(\mathrm{Ti}_{0.8} \mathrm{Mo}_{0.2}\right) \mathrm{C}-40 \mathrm{Ni}$, the milling time of Process II was $96 \mathrm{~h}$ in addition of $72 \mathrm{~h}$. The Vickers hardness with fracture toughness and the quantitative microstructural parameters were measured and analyzed. The relationship between fracture toughness and hardness for the cermets was on the fitted curve derived from the previous data for the cermets, except for the case of $\left(\mathrm{Ti}_{0.8} \mathrm{Mo}_{0.2}\right) \mathrm{C}-40 \mathrm{Ni}$ for $72 \mathrm{~h}$, which is lower fracture toughness than that for the previous works and $\left(\mathrm{Ti}_{0.8} \mathrm{Mo}_{0.2}\right) \mathrm{C}-40 \mathrm{Ni}$ for $96 \mathrm{~h}$. The contiguity of the samples tend to increase with increasing hard phase contents except for the case of $\left(\mathrm{Ti}_{0.8} \mathrm{Mo}_{0.2}\right) \mathrm{C}-40 \mathrm{Ni}$ for $72 \mathrm{~h}$, which is higher than those of $\left(\mathrm{Ti}_{0.8} \mathrm{Mo}_{0.2}\right) \mathrm{C}-40 \mathrm{Ni}$ for $96 \mathrm{~h}$. On the other hand, the coefficient of variation for hard phase of the both $\left(\mathrm{Ti}_{0.8} \mathrm{Mo}_{0.2}\right) \mathrm{C}-40 \mathrm{Ni}$ were almost same. [doi:10.2320/matertrans.M2014087]

(Received March 10, 2014; Accepted June 11, 2014; Published July 18, 2014)

Keywords: cermet, microstructure, hardness, fracture toughness

\section{Introduction}

Ti(C,N)-based cermet is one of the candidates for alternative materials to WC-Co, because they have high hardness, wear resistance and oxidation resistance. Therefore, the cermets have been investigated to improve the properties. The mechanical properties of $\mathrm{TiC}-\mathrm{Ni}$ cermet was reported in $1960 \mathrm{~s}^{1)}$ and transverse rupture strength (TRS) and hardness were as low as about $1 \mathrm{GPa}$ and $600 \mathrm{HV}$. Humenik and Parikh report $^{2,3}$ that molybdenum enhances the wettability between hard phase and binder phase. Actually, TRS and the hardness of cermets including molybdenum in $\mathrm{TiC}$ or $\mathrm{TiC}-\mathrm{TiN}$ were improved as above $1.5 \mathrm{GPa}$ and $1000 \mathrm{HV}^{4)}$ In addition, the various elements were added to improved various properties, for instance, WC to improve the wetting densification and fracture toughness ${ }^{5-7)}$ and $\mathrm{NbC}$ and $\mathrm{TaC}$ to improve the hot hardness and thermoshockresistance. ${ }^{7)}$ Resulting in the additive elements, the hard phase of the $\mathrm{Ti}(\mathrm{C}, \mathrm{N})$-based cermets become core-rim structures such as a $\mathrm{Ti}(\mathrm{C}, \mathrm{N})$ core and a $(\mathrm{Ti}, \mathrm{X}, \mathrm{Y})(\mathrm{C}, \mathrm{N})$ rim $(\mathrm{X}$ and $\mathrm{Y}$ denote the additive metallic elements).

It is thought that microstructural features strongly influence to mechanical properties and microstructural homogeneity leads to improvement of the mechanical properties. In the case of the cermets, however, relationship between microstructural homogeneity and mechanical properties has been unclear so far. The complicated microstructures, such as corerim structures, is one of the main causes of that.

Recently, the cermets with simple chemical compositions are refocused and reported as a result of resource problem. $^{8-16)}$ In this matter, $(\mathrm{Ti}, \mathrm{X}) \mathrm{C}$ or $(\mathrm{Ti}, \mathrm{X})(\mathrm{C}, \mathrm{N})$ solid solution cermets ${ }^{10,14-16)}$ have attracted attentions. However, there were few information about microstructural features and mechanical properties of solid solution cermets. In addition, besides these cermets have only solid soluted hard phases, the characteristics of them enables us to estimate microstructural features quantitatively and correlate with mechanical properties.
In the present work, $\left(\mathrm{Ti}_{0.8} \mathrm{Mo}_{0.2}\right) \mathrm{C}-\mathrm{Ni}$ solid solution cermets with $10-40$ mass $\% \mathrm{Ni}$ contents were prepared, and mechanical properties and the microstructures parameters were analyzed.

\section{Experimental Procedures}

The five $\left(\mathrm{Ti}_{0.8} \mathrm{Mo}_{0.2}\right) \mathrm{C}$-Ni cermets were prepared via two processes, hereafter they were called as Process I and Process II, respectively. Details of these processes are as follows:

Process I: titanium $(99.9 \%, 45 \mu \mathrm{m})$, carbon $(99.9 \%, 20 \mu \mathrm{m})$, and molybdenum $(>99.9 \%, 3 \mu \mathrm{m})$ powders were used as raw powders. These powders were sealed in a $500 \mathrm{ml}$ hardened steel pot together with $\mathrm{WC} / \mathrm{Co}$ ball and then were dry-mixed by a planetary ball milling machine for $250 \mathrm{~h}$ in an $\mathrm{Ar}$ atmosphere with $20: 1$ of the ball-to-powder weight ratio (BPR).

Process II: The powder produced by Process I and nickel $(>99.9 \%, 5 \mu \mathrm{m})$ powder were sealed in a $420 \mathrm{ml}$ stainless steel pot together with WC-Co balls were mixed in $100 \mathrm{ml}$ ethanol by tumbling ball milling for $72 \mathrm{~h}$ with $15: 1$ of BPR. $\left(\mathrm{Ti}_{0.8} \mathrm{Mo}_{0.2}\right) \mathrm{C}-40 \mathrm{Ni}$ produced by tumbling ball milling for $72 \mathrm{~h}$ indicate relatively higher contiguity of hard phase. Therefore, $\left(\mathrm{Ti}_{0.8} \mathrm{Mo}_{0.2}\right) \mathrm{C}-40 \mathrm{Ni}$ were also produced with $96 \mathrm{~h}$ of milling time in addition of $72 \mathrm{~h}$. After that, they were pressed under a pressure of $100 \mathrm{MPa}$ and then sintered at 1673 to $1723 \mathrm{~K}$ for $1 \mathrm{~h}$ under vacuum.

The microstructures of the sintered compacts were observed by field-emission scanning electron microscopy (FE-SEM). The image-processing software was used to measure the microstructural parameters. The hard phase mean grain size, $d_{\text {hard }}$, is calculated as

$$
d_{\text {hard }}=D \sqrt{\frac{3}{2}}
$$

where $D$ is the projected grain size actually measured on images. The perimeter of the carbonitride grains, $L_{\mathrm{hard}}$, and 


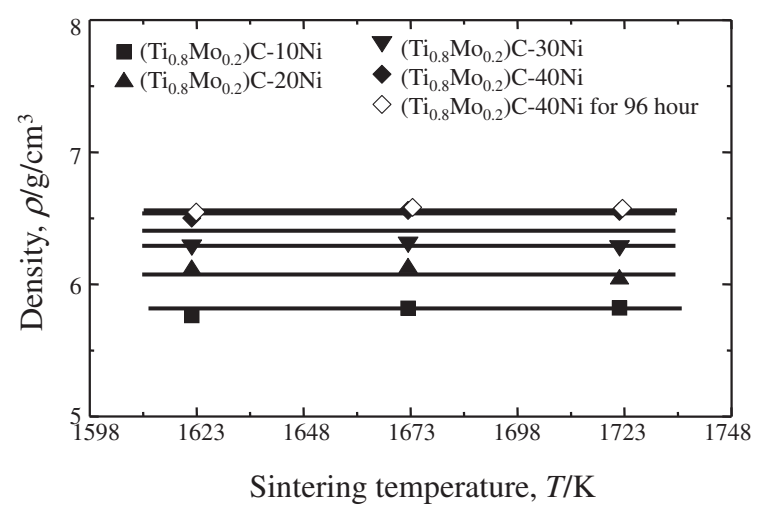

Fig. 1 Relationships between density and sintering temperature for the cermets.

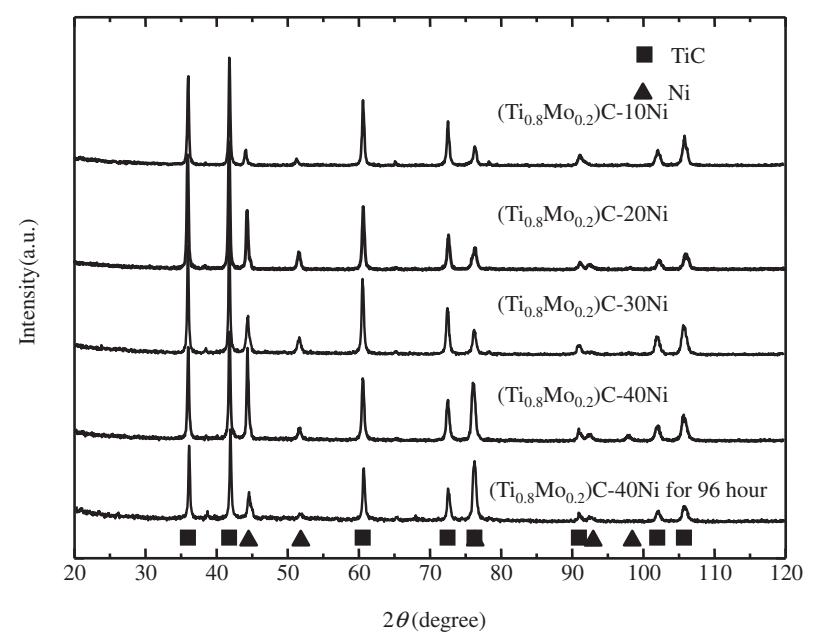

Fig. 2 XRD patterns for the cermets.
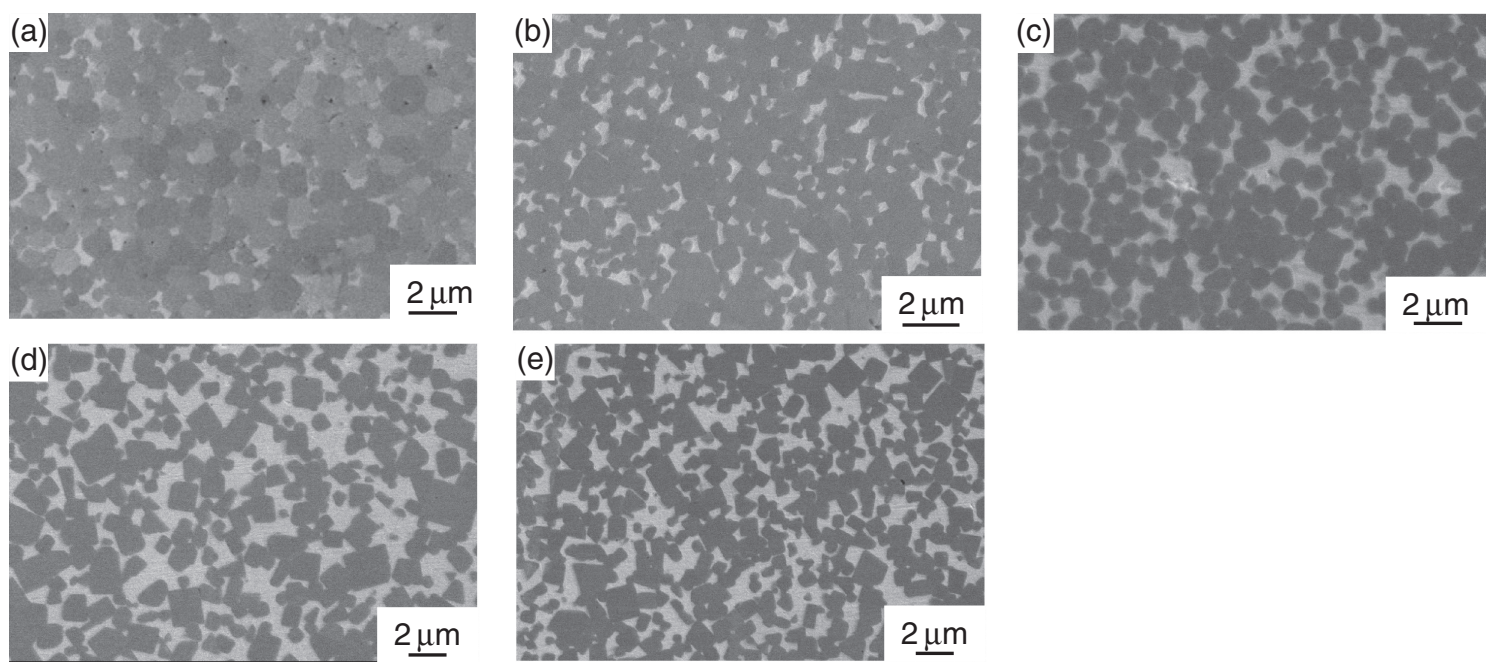

Fig. 3 Microstructures of Sintered Compacts: (a) $\left(\mathrm{Ti}_{0.8} \mathrm{Mo}_{0.2}\right) \mathrm{C}-10 \mathrm{Ni}$, (b) $\left(\mathrm{Ti}_{0.8} \mathrm{Mo}_{0.2}\right) \mathrm{C}-20 \mathrm{Ni}$, (c) $\left(\mathrm{Ti}_{0.8} \mathrm{Mo}_{0.2}\right) \mathrm{C}-30 \mathrm{Ni}$ and (d) $\left(\mathrm{Ti}_{0.8} \mathrm{Mo}_{0.2}\right) \mathrm{C}-40 \mathrm{Ni}$ with $72 \mathrm{~h}$ milling time and $(\mathrm{e})\left(\mathrm{Ti}_{0.8} \mathrm{Mo}_{0.2}\right) \mathrm{C}-40 \mathrm{Ni}$ with $96 \mathrm{~h}$ milling time.

that of the binder pockets, $L_{\text {binder, }}$ can be measured and the contiguity, $C_{\text {hard }}$, is defined as:

$$
C_{\text {hard }}=\frac{L_{\text {hard }}-L_{\text {binder }}}{L_{\text {hard }}}
$$

The coefficient of variation, $C V$, which is regarded as the hard phase size distribution, and is defined as:

$$
C V=\frac{\sigma}{d_{\mathrm{hard}}}
$$

where $\sigma$ is standard deviation of the hard phase size distribution, which is calculated from all hard phase grain size data.

The densities of the sintered compacts were measured by Archimedian method. The sintered compacts were analyzed by XRD using $\mathrm{Cu} \mathrm{K} \alpha$ radiation. Young's modulus, $E$, was obtained by ultrasonic pulse echo method, which provides velocities of longitudinal and shear waves in the specimen. The Vickers hardness tests were conducted with 294 N. The fracture toughness, $K_{\mathrm{IC}}$, was calculated from the length of the radial cracks originating in the corners of the Vickers indentations according to the formula proposed by Niihara et al. (IF method, Palmqvist-type). ${ }^{17)}$

\section{Results and Discussion}

Relationships between density and sintering temperature for the cermets are shown in Fig. 1. These densities increase with increasing Ni contents. Compared the $\left(\mathrm{Ti}_{0.8} \mathrm{Mo}_{0.2}\right) \mathrm{C}$ $40 \mathrm{Ni}$ for $72 \mathrm{~h}$ milling time to the $\left(\mathrm{Ti}_{0.8} \mathrm{Mo}_{0.2}\right) \mathrm{C}-40 \mathrm{Ni}$ for $96 \mathrm{~h}$ milling time, these are almost same densities. The densities of all samples are constant in the sintering temperature range, indicating that all samples are sufficiently dense.

The XRD patterns for the cermets are shown in Fig. 2. The all cermets indicated typical XRD patterns for the cermets, which means the peaks of TiC structure and nickel existed for them, although there are slight unknown peak at 39 degree in all the cermets. The angles for the nickel peaks trended toward a lower angle. It is considered that some $\mathrm{Mo}$ and $\mathrm{Ti}$ caused the shift of the nickel peak in this work as well as the other cermets. ${ }^{18)}$

The microstructures of the five cermets were observed by FE-SEM, as shown in Fig. 3. It is known that the core-rim structure of the hard phase shows a contrast between core $\mathrm{Ti}(\mathrm{C}, \mathrm{N})$ and $\operatorname{rim}(\mathrm{Ti}, \mathrm{X})(\mathrm{C}, \mathrm{N})$ in SEM observation. ${ }^{5,6,9,11,12)}$ However, the hard phase of the prepared cermets consisted of 


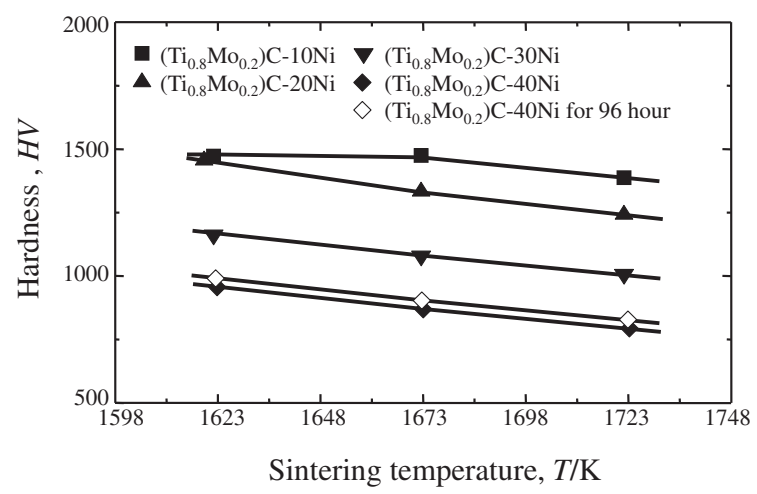

Fig. 4 Vickers hardness and sintering temperature of each cermets.

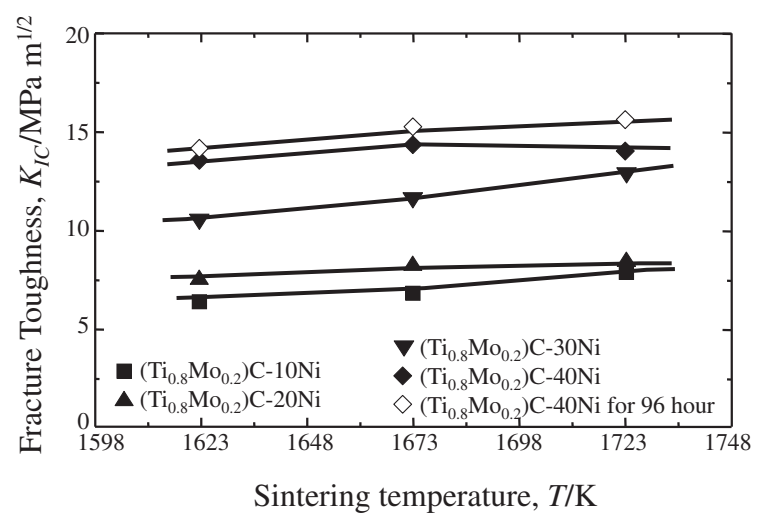

Fig. 5 Fracture toughness and sintering temperature of each cermets.

no contrast meaning solid soluted hard phase. The hard phase grain size of $\left(\mathrm{Ti}_{0.8} \mathrm{Mo}_{0.2}\right) \mathrm{C}-40 \mathrm{Ni}$ for $96 \mathrm{~h}$ milling time was smaller than that for $72 \mathrm{~h}$ milling time. It is indicated that milled powders became smaller with increase of milling time.

The Vickers hardness and sintering temperature is plotted in Fig. 4. The Vickers hardness decreased with increasing sintering temperature and $\mathrm{Ni}$ contents. Compared $\left(\mathrm{Ti}_{0.8} \mathrm{Mo}_{0.2}\right) \mathrm{C}-40 \mathrm{Ni}$ with $72 \mathrm{~h}$ milling time to $\left(\mathrm{Ti}_{0.8} \mathrm{Mo}_{0.2}\right) \mathrm{C}$ $40 \mathrm{Ni}$ with $96 \mathrm{~h}$ milling time, it with $96 \mathrm{~h}$ milling time were higher than that with $72 \mathrm{~h}$ milling time. The smaller hard phase grain size of it with $96 \mathrm{~h}$ milling time contributed to higher hardness.

The fracture toughness and sintering temperature of each cermets is plotted in Fig. 5. Fracture toughness for them basically increase with increasing sintering temperature and $\mathrm{Ni}$ contents. It is seen from Figs. 4 and 5 that the cermets with higher Vickers hardness indicated lower fracture toughness.

The relationship between fracture toughness and Vickers hardness for the cermets is shown in Fig. 6, where the highest relationships between fracture toughness and hardness in the sintering temperatures in this work. Besides the data in the previous works were plotted and the fitted curves for them described. The present data are on the curve, except for the case of $\left(\mathrm{Ti}_{0.8} \mathrm{Mo}_{0.2}\right) \mathrm{C}-40 \mathrm{Ni}$ with $72 \mathrm{~h}$ milling time. The fracture toughness for $\left(\mathrm{Ti}_{0.8} \mathrm{Mo}_{0.2}\right) \mathrm{C}-40 \mathrm{Ni}$ with $72 \mathrm{~h}$ milling time is clearly below the curve, and inferior to that with $96 \mathrm{~h}$ milling time.

It is well known that microstructural features, in particular, homogeneity is important to achieve good mechanical

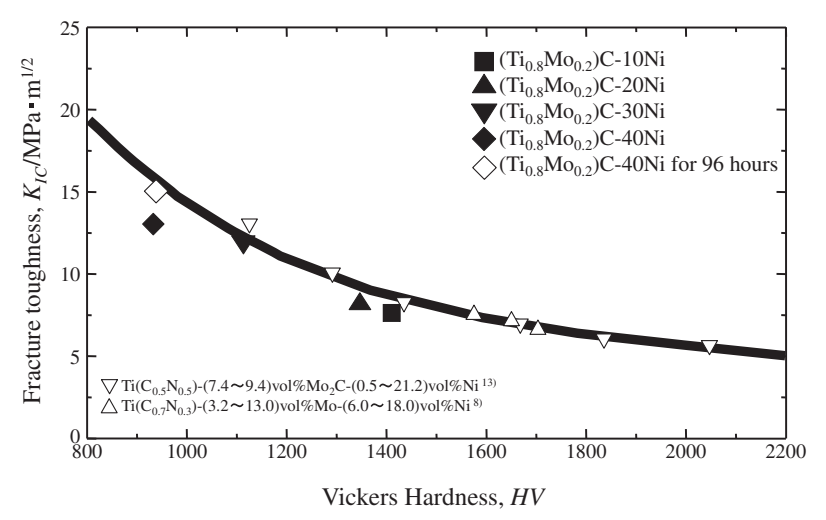

Fig. 6 Relationship between fracture toughness and Vickers hardness for the cermets, where the data for $\mathrm{TiCN}-\mathrm{Mo}_{2} \mathrm{C}-\mathrm{Ni}$ cermets in the previous works are superimposed. The line is the fitted curve for the data in the previous works.

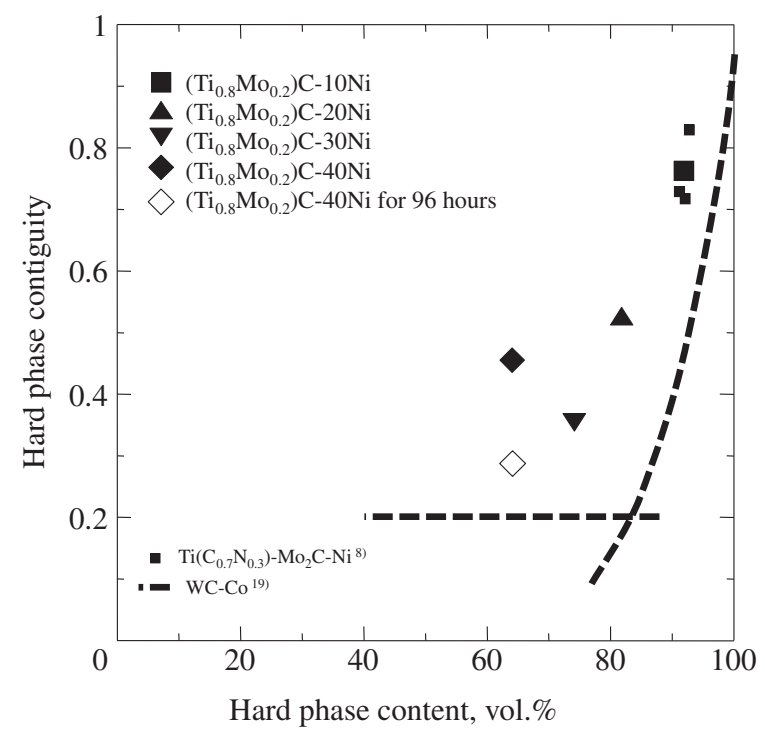

Fig. 7 Hard phase contiguity vs hard phase content for the cermets, the data for TiCN-Mo2C-Ni cermets in the previous works and the dash lines for the empirical equations of the relationship between hard phase contiguity and hard phase content for WC-Co are superimposed. ${ }^{19)}$

properties. $\left(\mathrm{Ti}_{0.8} \mathrm{Mo}_{0.2}\right) \mathrm{C}$-Ni are ceramic based composites with metal. In this case, homogeneity indicates dispersiveness and size distribution. The hard phase contiguity vs hard phase content for the cermets is shown in Fig. 7. The hard phase contiguity increases with increasing hard phase content, except for the case of $\left(\mathrm{Ti}_{0.8} \mathrm{Mo}_{0.2}\right) \mathrm{C}-40 \mathrm{Ni}$. This trend is the same to it for WC-Co. The levels of contiguity for the cermets are higher than those for WC-Co. There is unclear whether the contiguity for the cermets in this work is the best levels, however, the same to them in the previous work. The hard phase contiguity of the both $\left(\mathrm{Ti}_{0.8} \mathrm{Mo}_{0.2}\right) \mathrm{C}$ $40 \mathrm{Ni}$ with different milling time were visible difference, it of the $\left(\mathrm{Ti}_{0.8} \mathrm{Mo}_{0.2}\right) \mathrm{C}-40 \mathrm{Ni}$ with $72 \mathrm{~h}$ milling time was $30 \% \mathrm{up}$, compared to that of the $\left(\mathrm{Ti}_{0.8} \mathrm{Mo}_{0.2}\right) \mathrm{C}-40 \mathrm{Ni}$ with $96 \mathrm{~h}$ milling time.

The coefficient of variation for hard phase of the $\left(\mathrm{Ti}_{0.8} \mathrm{Mo}_{0.2}\right) \mathrm{C}-\mathrm{Ni}$ is shown in Fig. 8. The coefficient of variation for hard phase of the cermet were almost same, but slight different. In the high $\mathrm{Ni}$ content, they decrease with decreasing $\mathrm{Ni}$ content, on the other hand, below the 


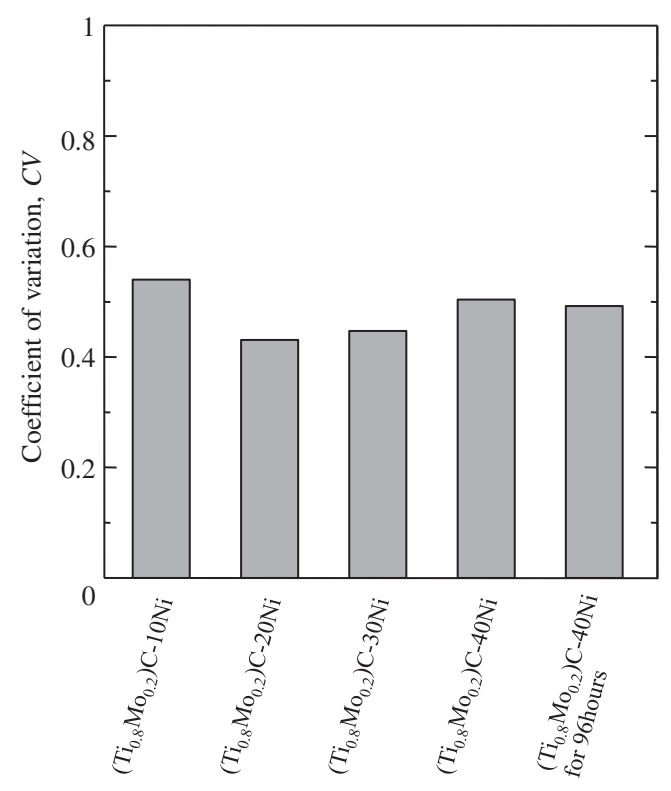

Fig. 8 The coefficient of variation of the $\left(\mathrm{Ti}_{0.8} \mathrm{Mo}_{0.2}\right) \mathrm{C}-\mathrm{Ni}$.

$\left(\mathrm{Ti}_{0.8} \mathrm{Mo}_{0.2}\right) \mathrm{C}-20 \mathrm{Ni}$, the value of the $\left(\mathrm{Ti}_{0.8} \mathrm{Mo}_{0.2}\right) \mathrm{C}-10 \mathrm{Ni}$ is higher than that of the $\left(\mathrm{Ti}_{0.8} \mathrm{Mo}_{0.2}\right) \mathrm{C}-20 \mathrm{Ni}$. Unfortunately, this trend is appropriate or not, because there are no report for the coefficient of variation for hard phase of the $\mathrm{TiC}-\mathrm{Ni}$ based cermets, which is in the future work. On the focus of the coefficient of variation for the both $\left(\mathrm{Ti}_{0.8} \mathrm{Mo}_{0.2}\right) \mathrm{C}-40 \mathrm{Ni}$ with different milling time, they are almost same.

As mentioned above, the hard phase contiguity of the $\left(\mathrm{Ti}_{0.8} \mathrm{Mo}_{0.2}\right) \mathrm{C}-40 \mathrm{Ni}$ with $72 \mathrm{~h}$ milling time was higher than that of the $\left(\mathrm{Ti}_{0.8} \mathrm{Mo}_{0.2}\right) \mathrm{C}-40 \mathrm{Ni}$ with $96 \mathrm{~h}$ milling time. On the other hand, the coefficient of variation for the both $\left(\mathrm{Ti}_{0.8} \mathrm{Mo}_{0.2}\right) \mathrm{C}-40 \mathrm{Ni}$ is the same. The mechanical properties for the cermets were almost same to the previous works except for the case of the $\left(\mathrm{Ti}_{0.8} \mathrm{Mo}_{0.2}\right) \mathrm{C}-40 \mathrm{Ni}$ with $72 \mathrm{~h}$ milling time, which had lower fracture toughness. Therefore, it is indicated that higher hard phase contiguity cause to inferior mechanical properties for the $\left(\mathrm{Ti}_{0.8} \mathrm{Mo}_{0.2}\right) \mathrm{C}-40 \mathrm{Ni}$ with $72 \mathrm{~h}$ milling time. It is considered that the hard phase contiguity ratio is more sensitive parameter to improve mechanical properties than the coefficient of variation for solid soluted (Ti,Mo)C-Ni cermets.

\section{Conclusion}

Five cermets were prepared via two processes, which are mechanical alloyed $\left(\mathrm{Ti}_{0.8} \mathrm{Mo}_{0.2}\right) \mathrm{C}$ powder and commercial $\mathrm{Ni}$ powder with tumbling ball mill, and the microstructures and the mechanical properties of them were observed and analyzed. The results can be listed as follows.

(1) The hard phase of the all prepared cermets consisted of two phase, i.e., hard phase and binder phase, and hard phase were a solid soluted phase.
(2) The hardness increased with decreasing Ni content, on the contrary, the fracture toughness increased with increasing $\mathrm{Ni}$ content for the prepared cermets. Relationship between hardness and fracture toughness for the cermets in this work is on the line deriving from the cermets in the previous works, except for the case of $\left(\mathrm{Ti}_{0.8} \mathrm{Mo}_{0.2}\right) \mathrm{C}-40 \mathrm{Ni}$ with $72 \mathrm{~h}$ milling time. The fracture toughness of $\left(\mathrm{Ti}_{0.8} \mathrm{Mo}_{0.2}\right) \mathrm{C}-40 \mathrm{Ni}$ with $72 \mathrm{~h}$ milling time had lower fracture toughness than that with $96 \mathrm{~h}$ milling time.

(3) The hard phase contiguity of the cermets decreased with decreasing hard phase contents, except for the case of $\left(\mathrm{Ti}_{0.8} \mathrm{Mo}_{0.2}\right) \mathrm{C}-40 \mathrm{Ni}$ with $72 \mathrm{~h}$ milling time. $\left(\mathrm{Ti}_{0.8} \mathrm{Mo}_{0.2}\right) \mathrm{C}$ $40 \mathrm{Ni}$ with $72 \mathrm{~h}$ milling time was clearly higher that that with $96 \mathrm{~h}$ milling time. On the other hand, the coefficient of variation for hard phase of the both $\left(\mathrm{Ti}_{0.8} \mathrm{Mo}_{0.2}\right) \mathrm{C}-40 \mathrm{Ni}$ were almost same.

\section{Acknowledgement}

This research was supported by The Amada Foundation.

\section{REFERENCES}

1) M. Sugiyama and H. Suzuki: J. Jpn. Inst. Met. 24 (1960) 689-692 (in Japanese).

2) M. Humenik, Jr. and N. M. Parikh: J. Am. Ceram. Soc. 39 (1956) 6063.

3) N. M. Parikh and M. Humenik, Jr.: J. Am. Ceram. Soc. 40 (1957) 315320.

4) H. Suzuki, K. Hayashi, O. Terada and M. Fukuda: J. Jpn. Soc. Powder Powder Metall. 21 (1974) 51-55 (in Japanese).

5) D. Mari, S. Bolognini, T. Viatte and W. Benoit: Int. J. Refract. Met. Hard Mater. 19 (2001) 257-265.

6) S. Ahn and S. Kang: Int. J. Refract. Met. Hard Mater. 19 (2001) 539545.

7) P. Ettmayer, H. Kolaska, W. Lengauer and K. Dreyer: J. Refract. Met. Hard Mater. 13 (1995) 343-351.

8) D. Mari, S. Bolognini, G. Feusier, T. Cutard, C. Verdon, T. Viatte and W. Benoit: J. Refract. Met. Hard Mater. 21 (2003) 37-46.

9) D. Mari, S. Bolognini, G. Feusier, T. Cutard, T. Viatte and W. Benoit: Int. J. Refract. Met. Hard Mater. 21 (2003) 47-53.

10) Y. K. Kim, J.-H. Shim, Y. W. Cho, H.-S. Yang and J.-K. Park: J. Refract. Met. Hard Mater. 22 (2004) 193-196.

11) S.-Y. Ahn and S. Kang: Scr. Mater. 55 (2006) 1015-1018.

12) Y. Li, N. Liu, X. Zhang and C. Rong: J. Refract. Met. Hard Mater. 26 (2008) 33-40.

13) T. Ogura, T. Shoji, A. Sasaki, O. Terada and H. Hayashi: Abstract Autumn Meeting, J. Soc. Powder Powder Met. (2009) p. 132.

14) S. Park and S. Kang: Scr. Mater. 52 (2005) 129-133.

15) H. Hosokawa, K. Kato, K. Shimojima and A. Matsumoto: Mater. Trans. 50 (2009) 117-122.

16) H. Hosokawa, K. Kato, K. Shimojima and A. Matsumoto: Mater. Trans. 51 (2010) 1428-1432.

17) K. Niihara, R. Morena and D. P. H. Hasselman: J. Mater. Sci. Lett. 1 (1982) 13-16.

18) H. Suzuki, K. Hayashi, H. Matsubara and K. Tokumoto: J. Jpn. Soc. Powder Powder Metall. 30 (1983) 106-111 (in Japanese).

19) S. Luyckx and A. Love: Int. J. Refract. Met. Hard Mater. 24 (2006) 7579. 